penetrating chest wounds over the past seven years. No deaths can be attributed to this conservative approach, although urgent thoracotomy, hours after admission, because of sudden haemodynamic deterioration has been required in a few patients in whom immediate thoracotomy was not performed.

Transfer to a specialised unit is clearly out of the question for group 3 patients and may be dangerous for those in group 2. Lack of training in cardiothoracic surgery should not deter the receiving surgical staff from performing immediate or urgent anterolateral thoracotomy when necessary. Likewise, so rarely is cardiopulmonary bypass essential for patient survival that the lack of such facilities should not preclude immediate operation. Only with judicious surgical intervention will the excellent results currently reported in the United States be achieved in Britain. ${ }^{7}$

D P TAGGART Lecturer

I J REECE Senior lecturer

University Department of Cardiac Surgery,

Royal Infirmary,

Glasgow G31 2ER

1 Goiti JJ, Smith GH. Emergency surgery for stab wound to the heart. Ann R Coll Surg Eng 1984;66:221-2.

2 Lambrianides AL, Rosin RD. Penetrating stab injuries of the chest and abdomen. Injury 1984;15:300-3.

3 Swann IJ, Macmillan R, Watson AA. A study of stab wounds. Arch Emerg Med 1985;2:31-6.

4 Society of Thoracic and Cardiovascular Surgeons. UK thoracic surgical register results: 1980, 1981 1982 and 1983. Northern General Hospital, Sheffield: Society of Thoracic and Cardiovascular 1982 and 1983 . Northern General Hospital, Sheffeld:

5 Reece IJ, Davidson KG. Emergency surgery for stab wounds to the heart. Ann R Coll Surg Engl 1983;65:304-7.

6 Kish G, Kozloff L, Joseph WL, Adkins PC. Indications for early thoracotomy in the management of chest trauma. Ann Thorac Surg 1976;22:23-8.

7 Ivatury RR, Shah PM, Katsuki I, Ramirez-Schon G, Suarez F, Rohman M. Emergency room thoracotomy for the resuscitation of patients with "fatal" penetrating injuries of the heart. Ann Thorac Surg 1981;32:377-85.

8 Siemens R, Polk HC, Gray LA, Fulton RL. Indications for thoracotomy following penetrating thoracic injury. $\mathcal{F}$ Trauma 1977;17:493-500.

9 Beck CS. Wounds of the heart. Arch Surg 1926;13:205-27.

10 Demetriades D. Cardiac wounds. Experience with 70 patients. Ann Surg 1986;203:315-7.

11 Miller FA, Seward JB, Gersh BJ, Tajik AJ, Mucha P. Two-dimensional echocardiographic findings in cardiac trauma. Am $\mathcal{F}$ Cardiol 1982;50:1022-7.

12 Oparah SS, Mandal AK. Operative management of penetrating wounds of the chest in civilian practice. Review of indications in 125 consecutive patients. I Thorac Cardiovasc Surg practice. Review $1979 ; 77: 162-8$.

13 Demetriades D. Cardiac penetrating injuries: personal experience of 45 cases. $\mathrm{Br} \mathcal{~}$ Surg 1984;71:95-7.

14 Keen C. Chest injuries: a guide for the accident department. Bristol: John Wright and Sons Ltd, 1975:108-15.

15 De Gennaro VA, Bonfils-Roberts EA, Ching N, Nealon TF. $f$ Thorac Cardiovasc Surg 1980;79:833-7.

\section{McKeown reassessed}

In The Modern Rise of Population McKeown concluded that the fall in mortality in Britain during the nineteenth century was caused principally by improvements in nutrition, which challenged the prevailing view that it had been caused by advances in medicine. ' Szreter has re-examined McKeown's thesis, which gives us the opportunity of asking, "Was McKeown right about nutrition?" and "Is the cause of the decline in nineteenth century mortality relevant today?"2

The modern rise of the population is a phenomenon of extraordinary proportions. In England and Wales it rose from under 6 million in 1700 to 18 million in 1851 and 49 million in 1971 . World wide it doubled from 1000 million (1830) to 2000 million (1930) in 100 years and doubled again to 4000 million (1975) in a further 45 years. The rise is generally agreed to have been caused by a fall in mortality rather than an increase in birth rates. What McKeown did was to analyse the number and causes of death from the time that reliable and systematic records began in 1837 . Observing that it was the fall in mortality from infectious disease that contributed most to the overall decline, he considered several possible factors that might have influenced the relation between organism and host, including an autonomous decline in the virulence of the organism, a reduction in exposure, an improvement in the host's defensive system, and an improvement in the methods of treatment. He considered each in turn and dismissed them all except improved nutrition leading to an improvement in the host's defences.

McKeown tested the hypothesis that there had been either an increase in food consumption per head, or an improvement in the quality of food. His estimates of increased food consumption came from three sources: increased land under cultivation; increased yields for each acre; and increased food imports. Land use and farming methods changed appreciably. Rotation of crops, winter feeding of cattle, and the use of manure all increased. New crops were introduced from the Low Countries, including turnips, beets, carrots, and parsnips; and tubers, including potatoes and artichokes, were brought in from America. ${ }^{3}$ Potato yields increased, particularly in Ireland. Improved transport led to large increases in food imports from the United States, Canada, and Australasia.

Nevertheless, Healy and Jones analysed wheat yields between 1817 and 1839 and concluded that the increase of $17 \%$ was well below the population increase of $36 \% .{ }^{4}$ Razzell concluded that for coffee, which was primarily a middle class drink, and potatoes there was no evidence of increased food intake per head. ${ }^{5}$ Furthermore, nutritional changes should have had the greatest impact on those with insufficient diet, but the most dramatic changes seem to have been in social class I. This has been clearly shown by Hollingworth's study of the life expectancy of the British peerage from 1700 to $1850 .^{6}$

McKeown argued that the key to the overall decline in mortality was the drop in airborne rather than waterborne or foodborne diseases, which is what influenced his judgment that nutrition was more important than public health measures. Szreter, using the same data for 1850-1971, questioned the classification of deaths from tuberculosis and bronchitis and argued that it was the decline in deaths from waterborne and foodborne diseases and therefore public health measures that were likely to have been the most important. McKeown's hypothesis remains attractive, particularly when it is applied to the period 1750-1850, when public health measures were almost non-existent. Razzell, however, has introduced a different hypothesis to cover this earlier period-that is, that personal hygiene improved dramatically. ${ }^{5} \mathrm{He}$ cites the associated increase in the consumption of soap and in the sale and use of washable cotton clothes. Razzell also has strong criticisms of McKeown's dismissal of the importance of smallpox inoculation: before 1837 smallpox had been an important contributor to overall mortality.

Was McKeown right? Before concluding that a plausible association is causal the epidemiologist considers the strength of the association; its consistency, specificity, and temporal relation; whether a dose response relation exists; and, finally, whether the association can be tested through experiment. Plausible associations by themselves are not enough and will tend to be biased towards the fashionable thinking of the time. The only way to get close to explaining the fall in 
mortality is to test the specific hypothesis in different places and at different times. Earlier records are available: births and deaths were registered nationally in Sweden from 1749 and in France from 1800. New documents may be unearthed that will throw light on, for example, the actual consumption of food during the last century, and comparisons with other countries at the same time may be of special value. Preston and Nelson studied the structure and changes in causes of death using data from 165 national populations. ${ }^{7}$ New techniques of analysis may make easier the separation of different factors operating at the same time. ${ }^{89}$ Whatever the technique, causes are not going to be proved; the most that can be hoped is to test the various hypotheses and eliminate those that fail. On balance, the nutritional hypothesis still seems the most powerful in explaining the decline in mortality, but the mechanism is probably to do with qualitative aspects of diet rather than simply increases per head.

Finally, does understanding the cause of the reductions in nineteenth century mortality have any relevance today? There are several current questions that have a direct relation to the last century. Why are there consistent differences between the mortality of the rich and the poor? Why is mortality two to three times higher for the unemployed than the employed? Why are there regional differences in mortality within Britain? Why is mortality from ischaemic heart disease and cervical cancer falling in some countries, static in some, and rising in others? What is the relation between economic growth and national mortality in both developed and developing countries?

What we owe to McKeown is not the answer to the puzzling fall in nineteenth century mortality but the example of his challenge to the then current mythology. Griffiths, for example, believed that the understanding of anatomy and physiology, the changes in medical education, the expansion of the hospital system, the growth of dispensaries, and the introduction of midwifery services and of specific measures against smallpox were the principal causes of the decline in mortality. ${ }^{10}$ McKeown's challenge threatened the supremacy of scientific medicine and the beliefs of the medical establishment and ranks in terms of heresy with the work of Cochrane $^{11}$ and Illich. ${ }^{12}$ McKeown was important because he brought to an old problem a new way of thinking that is fundamental to our understanding of many contemporary public health problems.

\section{S C FARROW}

Senior Lecturer in Epidemiology/Medical Care,

University of Wales College of Medicine,

Cardiff CF4 4XN

1 McKeown T. The modern rise of population. London: Edward Arnold, 1976.

2 Szreter S. The importance of social intervention in Britain's mortality decline c. 1850-1914: a re-interpretation. London: Centre for Economic Policy Research, 1986. (Discussion paper No 121.

3 Langer WL. American foods and European population growth. 1750-1850. Fournal of Social History 1975;1:51-66.

4 Healy MJR, Jones EL. Wheat yields in England 1815-59. Fournal of the Royal Statistical Society Series $A$ 1962;125:574-9.

5 Razzell PE. An interpretation of the modern rise of population in Europe: a critique. Population. Studies 1974;28:5-17.

6 Hollingsworth TH. The demography of the British peerage. Population Studies Supplement 1964;18:1-108.

7 Preston SH, Nelson VE. Structure and change in causes of death: an international summary. Population Studies 1974;281:19-51.

8 Case RAM. Cohort analysis of morbidity rates as an historical or narrative technique. British Journal of Preventive and Social Medicine 1956;10:159-71.

9 Osmond C, Gardner MJ. Age, period and cohort models applied to cancer mortality rates. Stat Med 1982;1:245-59.

10 Griffiths GT. Population problems in the age of Malthus. London: Frank Cass, 1967.

11 Cochrane A. Effectiveness and efficiency, random reflections on health services. London: Nuffield Provincial Hospitals Trust, 1972.

12 Illich I. Medical nemesis, the expropriation of health. London: Calder and Boyars, 1975.

\section{Aetiology of acute appendicitis}

The incidence of acute appendicitis is declining, but it remains the commonest cause of abdominal operations in Britain-and we still do not know what causes it. An imaginative attempt to solve the problem was made when the Medical Research Council Environmental Epidemiology Unit at Southampton invited a group of surgeons, physicians, epidemiologists, nutritionists, immunologists, gut physiologists, histopathologists, and microbiologists to discuss the aetiology of this disease. Many new ideas were aired, and the lack of fibre theory was made to look decidedly shaky.

The lack of fibre theory was proposed early in this century, when appendicitis was a new disease and still increasing. The theory was boosted in the 1970s by evidence that the disease was still rare in many rural areas of developing countries, where stools are bulky and gut transit is fast. ${ }^{2-4}$ Recently workers in South Africa have had second thoughts: they noticed that urban blacks had for several years been eating little fibre, even less than the whites, yet they remained free of appendicitis. ${ }^{5}$ Furthermore, the British mortality from appendicitis began to decline during the 1930s and has continued to fall ever since, whereas fibre intakes have increased only recently. ${ }^{6}$ Falling mortality may not be caused wholly by falling incidence. But there are other unexplained facts - for example, hospital admissions for appendicitis are 70\% commoner in Eire than in England.

Some workers have reported that the diet of patients with appendicitis contains less fibre than that of the general population, but others have not found this..$^{8-13}$ An odd dietary finding is that when different areas of the country are compared potato consumption is positively correlated with the disease (also sugar consumption, but less consistently), whereas a high intake of fruit and vegetables other than potato is associated with a lower incidence. ${ }^{14}$ Extension of these comparisons to include Scotland and Ireland confirms these findings and also shows that rates of appendicitis are highest in communities with high cereal consumption. ${ }^{15}$ Fitting all these facts into a neat and all embracing dietary hypothesis is hard, but environmental factors must be important in a disease whose incidence seems to change so fast. What other possibilities are there?

The infection theory is reviving in a new form. In the fully fledged disease bacteria invade and destroy the appendix, but bacteriology cannot explain why this happens. Most people believe it happens only when there is an obstruction of the appendicular lumen with stasis distally. In older people an impacted faecolith is sometimes found but not invariably; in young patients swelling of the lympathic tissue at the base of the appendix is a more likely cause of obstruction. This tissue swells with virus infections but atrophies with age.

Barker has combined these considerations with new epidemiological findings to generate a "hygiene hypothesis" for appendicitis. ${ }^{615}$ This attributes the rise in appendicitis to improvements in sewage disposal and water supplies in Britain in the late nineteenth century. These improvements in hygiene greatly reduced the exposure of infants and children to enteric organisms, which in turn altered the shildren's response to later virus infections so that they now criggered appendicitis. The virus did this either by causing vigorous lymphoid hyperplasia that blocked the appendix or conceivably by "devitalising" the appendiceal mucosa so that bacteria could invade. ${ }^{15}$

Barker attributes the fall in appendicitis in the past 50 years to improved housing leading to less overcrowding and 